\title{
Estimations of soil fertility in physically degraded agricultural soils through selective accounting of fine earth and gravel fractions
}

\author{
Mavinakoppa S. Nagaraja ${ }^{1}$, Ajay Kumar Bhardwaj ${ }^{1,2}$, G. V. Prabhakara Reddy ${ }^{3}$, Chilakunda A. Srinivasamurthy ${ }^{3}$, \\ and Sandeep Kumar ${ }^{4}$ \\ ${ }^{1}$ College of Horticulture, University of Horticultural Sciences, Bagalkot, 587102, India \\ ${ }^{2}$ Division of Soil and Crop Management, ICAR-Central Soil Salinity Research Institute, Karnal, 132001, India \\ ${ }^{3}$ Department of Soil Science, University of Agricultural Sciences, Bangalore, 587165, India \\ ${ }^{4}$ Department of Plant Science, South Dakota State University, Brookings, SD 57007, USA
}

Correspondence to: Ajay Kumar Bhardwaj (ak.bhardwaj@icar.gov.in) and Sandeep Kumar (sandeep.kumar@sdstate.edu)

Received: 2 February 2016 - Published in Solid Earth Discuss.: 23 February 2016

Revised: 18 May 2016 - Accepted: 18 May 2016 - Published: 7 June 2016

\begin{abstract}
Soil fertility and organic carbon (C) stock estimations are crucial to soil management, especially that of degraded soils, for productive agricultural use and in soil $\mathrm{C}$ sequestration studies. Currently, estimations based on generalized soil mass (hectare furrow basis) or bulk density are used which may be suitable for normal agricultural soils, but not for degraded soils. In this study, soil organic $\mathrm{C}$, available nitrogen $(\mathrm{N})$, available phosphorus $\left(\mathrm{P}_{2} \mathrm{O}_{5}\right)$ and available potassium $\left(\mathrm{K}_{2} \mathrm{O}\right)$, and their stocks were estimated using three methods: (i) generalized soil mass (GSM, 2 million $\mathrm{kg} \mathrm{ha}^{-1}$ furrow soil), (ii) bulk-density-based soil mass (BDSM) and (iii) the proportion of fine earth volume (FEV) method, for soils sampled from physically degraded lands in the eastern dry zone of Karnataka State in India. Comparative analyses using these methods revealed that the soil organic $\mathrm{C}, \mathrm{N}, \mathrm{P}_{2} \mathrm{O}$ and $\mathrm{K}_{2} \mathrm{O}$ stocks determined by using BDSM were higher than those determined by the GSM method. The soil organic $\mathrm{C}$ values were the lowest in the FEV method. The GSM method overestimated soil organic $\mathrm{C}, \mathrm{N}, \mathrm{P}_{2} \mathrm{O}$ and $\mathrm{K}_{2} \mathrm{O}$ by $9.3-72.1,9.5-72.3,7.1-66.6$ and $9.2-72.3 \%$, respectively, compared to FEV-based estimations for physically degraded soils. The differences among the three methods of estimation were lower in soils with low gravel content and increased with an increase in gravel volume. There was overestimation of soil organic C and soil fertility with GSM and BDSM methods. A reassessment of methods of estimation was, therefore, attempted to provide fair estimates for land development projects in degraded lands.
\end{abstract}

\section{Introduction}

Precise soil fertility and crop nutrition assessments are important for sustainable productivity in agricultural lands, especially in soils with inherent low carbon or high degradation. Mass-volume relationships are crucial in estimating soil fertility (Hartemink, 2006) and in developing reclamation plans. In recent years, these relationships have been used in soil carbon (C) stock estimations to assess the sink-source potential of soils for atmospheric carbon dioxide (Lorenz and Lal, 2005) and responses from management under different climatic conditions (Zubrzycki et al., 2014; Srinivasarao et al., 2014; Lozano-Garcia and Parras-Alcantara, 2014; ParrasAlcantara et al., 2015; Kaleem Abbasi et al., 2015). The calculations are based on the soil organic $\mathrm{C}$ and nutrient concentrations assessed for a few grams of soil and are translated later to a generalized soil mass (GSM) of $2 \times$ density of $1330 \mathrm{~kg} \mathrm{~m}^{-3}$. This assumed GSM refers mostly to soils that generally have equal proportions of solids and void space, with a negligible amount of gravel. In these estimations, therefore, importance is given to total mass instead of the actual soil mass based on field bulk density or the proportional volume of fine soil (without gravel proportion). However, in physically degraded soils, gravel content is at least $15 \%$ of the total soil volume (Soil Survey Division Staff, 1993). The amount of gravel present in soil affects bulk density and availability of nutrients (Poesen and Lavee, 1994; Van Wesemael et al., 2000). Hence, void space occupied by gravel can hardly be ignored. High gravel content can affect the ac- 


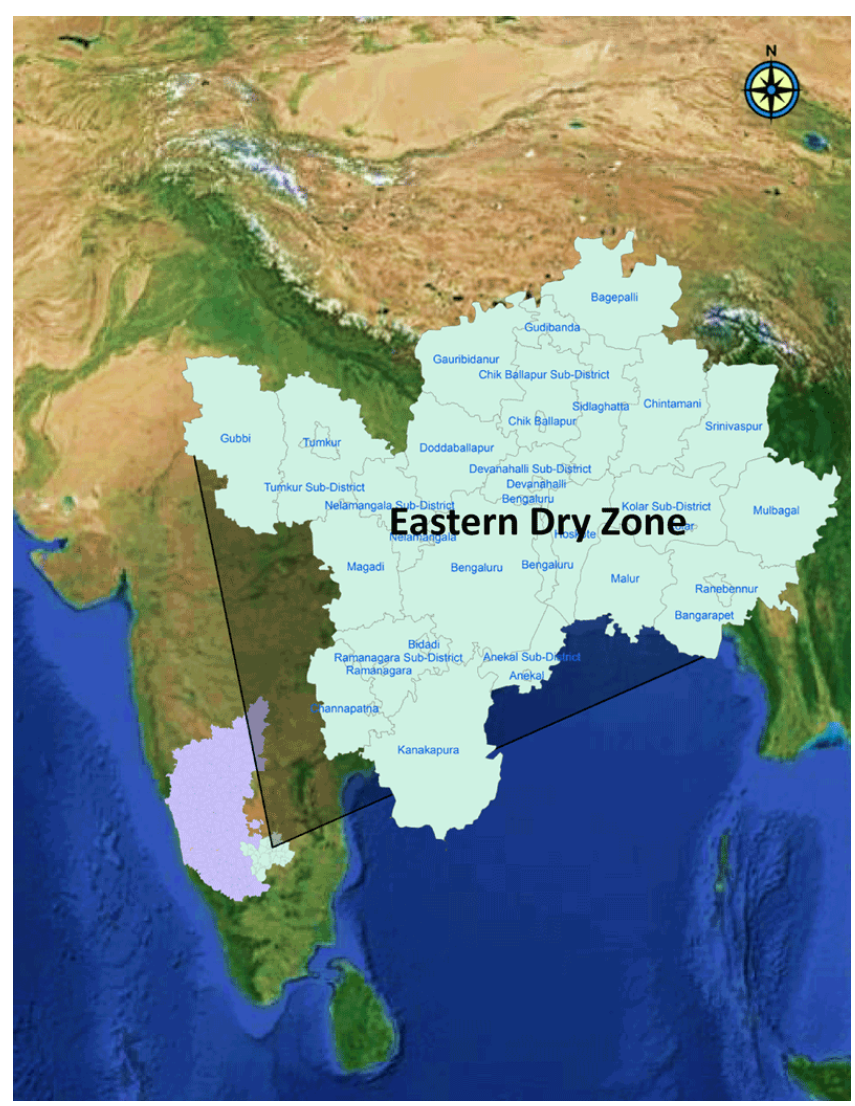

Figure 1. The location of sampling sites and study area.

curacy of soil fertility estimations in degraded soils if estimations are only based on GSM. However, given the importance of reclaiming degraded soils and exploiting them for agriculture or any other land use under climate change mitigation projects, accurate estimation of soil fertility becomes important (Mishra et al., 2015), both for location-specific nutrient applications and assessment of $\mathrm{CO}_{2}$ sink-source potential (Hartemink, 2006). Precise quantitative assessments help land developers and farmers to select management plans best suited to available soil resources, as well as to obtain realistic responses from management (Karlen et al., 2003; ParrasAlcantara et al., 2015; Lozano-Garcia et al., 2016).

Estimations with GSM may not be realistic for all soils as bulk density values are not the same (Arvidsson, 1999; Hartemink, 2006). Alternatively, the use of undisturbed field bulk density values in nutrient estimations appears more pragmatic. However, increase in gravel content, as seen in physically degraded soils, adds to the field bulk density values which can further overestimate soil fertility (Nagaraja and Srinivasamurthy, 2009). In reality, physically degraded soils could have a greater proportion of coarse fragments as the fine fractions are physically eroded. Erosion of soil leading to reduction in soil productivity has been well reported (Pierce et al., 1983; Pimentel et al., 1995; Jagadamma et al., 2009). The increase in the proportion of coarse frag- ments in soil reduces the volume of space effectively available for water and nutrient retentions, and also for plant root explorations (Grewal et al., 1984; Rao and Jessy, 2007; Nagaraja and Srinivasamurthy, 2009). In other words, the quantity of soil organic $\mathrm{C}$ and potentially available nutrients for plant uptake decrease with an increase in volume of coarse fragments, especially in agricultural soils (Hamarashid et al., 2010). Therefore, soil organic $C$ and nutrients are generally expected to decline with an increase in gravel content. This suggests that their estimations would be more realistic if they were based on fine earth volume instead of on generalized soil mass or even bulk-density-based estimations. This argument might hold well, especially for agricultural soils, while for forest ecosystems there are several theories highlighting the role of coarse fragments/rocks in biogeochemical cycles (Silver et al., 2000; Kohler, 2000; Heisner et al., 2004).

The eastern dry zone of Karnataka state in South India is considered as a bioresource-deficient zone for agricultural purposes (Ramachandran et al., 2004), where almost 50\% of rain falls during July to October. The soils are coarsetextured, with a predominance of gravel. Management of soil fertility in the soils of the region is crucial to support good productivity under water stress, which is prevalent during most parts of the year. Soil fertility estimations are crucial, therefore, to plan fertilizer inputs. Hypothetical estimations suggested that the GSM method would overestimate nutrient content for the degraded soils of this region and, therefore, the current practice of using this method needs to be modified (Nagaraja and Srinivasamurthy, 2009). However, this needs validation with actual field data before deciding the methodology for nutrient estimations. Therefore, this study was undertaken to evaluate the effect of three estimations: generalized soil-mass-based estimation (GSM), bulk-density-based estimation (BDSM) and fine-earth-volume-based estimation (FEV) methods for the assessment of soil $\mathrm{C}$ and nutrient stocks for physically degraded soils of the eastern dry zone of Karnataka state in India. These estimations are crucial to land use and land development programs most often implemented in resource-deficient zones, like the one under investigation, in other parts of the world.

\section{Methods}

\subsection{Study area}

The study area consisted of 18 sites in the eastern dry zone of Karnataka state in India, covering parts of Bangalore, Kolar and Tumkur districts (Fig. 1). The annual rainfall in the area ranges from 679 to $889 \mathrm{~mm}$. The predominant soils of the region are red soils (USDA suborder classification: Ustalfs; FAO/UNESCO equivalent: Planosols/Luvisols) overlying granite from which they are formed, with texture varying from gravely sandy loam to sandy clay loam (Soils of Karnataka, 1998). A preliminary survey was carried out 
Table 1. Physical and chemical characteristics of physically degraded wasteland soils compared to normal soils in the eastern dry zone of Karnataka. (WHC is water holding capacity; EC is electrical conductivity.)

\begin{tabular}{|c|c|c|}
\hline Parameters & $\begin{array}{l}\text { Normal area } \\
\text { soil }(n=18)\end{array}$ & $\begin{array}{l}\text { Degraded area } \\
\text { soil }(n=18)\end{array}$ \\
\hline \multicolumn{3}{|c|}{ Physical and chemical properties } \\
\hline Gravel (\%) & $12.3 \pm 4.06$ & $54.2 \pm 14.21$ \\
\hline Bulk density $\left(\mathrm{g} \mathrm{cm}^{-3}\right)$ & $1.38 \pm 0.06$ & $1.62 \pm 0.08$ \\
\hline Max WHC & $40.0 \pm 2.65$ & $32.04 \pm 3.30$ \\
\hline Field capacity $(\%)$ & $25.5 \pm 2.31$ & $18.5 \pm 3.61$ \\
\hline $\mathrm{pH}(1: 2.5)$ & $6.66 \pm 0.20$ & $6.64 \pm 0.25$ \\
\hline $\mathrm{EC}(1: 1.25)$ & $0.09 \pm 0.04$ & $0.07 \pm 0.02$ \\
\hline Organic C (\%) & $0.63 \pm 0.14$ & $0.45 \pm 0.18$ \\
\hline \multicolumn{3}{|c|}{ Available major nutrients } \\
\hline Available $-\mathrm{N}\left(\mathrm{kg} \mathrm{ha}^{-1}\right)$ & $264.66 \pm 24.70$ & $160.81 \pm 32.2$ \\
\hline Available $-\mathrm{P}_{2} \mathrm{O}_{5}\left(\mathrm{~kg} \mathrm{ha}^{-1}\right)$ & $26.75 \pm 10.32$ & $16.20 \pm 6.18$ \\
\hline Available $-\mathrm{K}_{2} \mathrm{O}\left(\mathrm{kg} \mathrm{ha}^{-1}\right)$ & $202.33 \pm 62.10$ & $163.88 \pm 41.01$ \\
\hline \multicolumn{3}{|c|}{ Available secondary nutrients } \\
\hline Exch. $\mathrm{Ca}\left(\mathrm{cmol}(p+) \mathrm{kg}^{-1}\right)$ & $5.50 \pm 1.21$ & $4.52 \pm 0.91$ \\
\hline Exch. $\operatorname{Mg}\left(\operatorname{cmol}(p+) \mathrm{kg}^{-1}\right)$ & $2.97 \pm 0.57$ & $1.98 \pm 0.17$ \\
\hline Available $\mathrm{S}\left(\mathrm{kg} \mathrm{ha}^{-1}\right)$ & $43.93 \pm 11.54$ & $22.80 \pm 6.15$ \\
\hline
\end{tabular}

initially in the entire eastern dry zone. Available information was gathered from various secondary sources such as the Department of Statistics, the Department of Agriculture and the Department of Forests to locate the existing physically degraded (eroded) lands in this red soil region. Based on the existing secondary information, a physical survey was carried out later by traversing through the region to choose 18 different sites for soil sampling. The locations of the sampling sites are depicted in Fig. 1. The exact sampling locations were fixed after giving regard to the visible features such as vegetation, magnitude of erosion and surface gravel content. Samples of agricultural and non-agricultural soils at the same sites were collected to include a wide range of gravel proportions (Table 1).

\subsection{Collection of soil samples for comparative analysis}

Surface soil up to $15 \mathrm{~cm}$ depth was collected using a sampling core. For each sites, two locations were identified with lands exposed to different magnitudes of erosion. At each location (sampling point), three samples were collected in close vicinity. The samples were carried to the laboratory to analyze the volumetric distribution of fine earth and coarse fragments (gravel) in the soil. The samples were air-dried and separated into coarse fragments $(>2 \mathrm{~mm})$ and fine earth $(<2 \mathrm{~mm})$ by sieving. These separate quantities were weighed and the proportion of coarse fragments was derived on a weight basis. The coarse fragments in the soils were of granite-gneiss origin. Coarse fragments retained on the sieve were washed with a jet of water and their respective volumes were determined by a volumetric water displacement method (Jalota et al., 1998). Finally, the volume of coarse fragments was deducted from the bulk soil volume to assess the proportional volume of fine earth.

The undisturbed core method was used for determination of bulk density (Jalota et al., 1998). The soil organic C was determined using the wet combustion method (Mebius, 1960; Schumacher, 2002), and was then used in estimating soil organic C stocks for different mass-volume relationships. Available nitrogen $(\mathrm{N})$ was determined according to Subbiah and Asija (1956), phosphorus $\left(\mathrm{P}_{2} \mathrm{O}_{5}\right)$ was determined colorimetrically using a spectrophotometer (Olsen et al., 1954) and potassium $\left(\mathrm{K}_{2} \mathrm{O}\right)$ was determined following the method used by Hanway and Heidel (1952).

\subsection{Stock estimation methods}

\subsubsection{Generalized soil mass (GSM) method}

The stocks (of $\mathrm{C}$ and nutrients) were estimated by multiplying the laboratory-determined $\mathrm{C}$ and nutrient values (in $\mathrm{g} \mathrm{kg}^{-1}$ ) with 1 ha furrow soil. A soil mass of 2 million $\mathrm{kg}$ to a depth of $15 \mathrm{~cm}$ with an assumed soil bulk density of $1330 \mathrm{~kg} \mathrm{~m}^{-3}$ was used to represent 1 ha furrow soil.

\subsubsection{Bulk-density-based soil mass (BDSM) method}

The total stocks (of $\mathrm{C}$ and nutrients) were estimated by multiplying the values (in $\mathrm{g} \mathrm{kg}^{-1}$ ) with a volume of soil ( 1 ha $\times 15 \mathrm{~cm}$ depth) and the field-measured bulk density (total mass per unit volume).

\subsubsection{Fine-earth-volume-based (FEV) method}

The total stocks (of $\mathrm{C}$ and nutrients) were estimated by multiplying the values (in $\mathrm{g} \mathrm{kg}^{-1}$ ) with a volume of soil $(1 \mathrm{ha} \times 15 \mathrm{~cm}$ depth) and the fine earth mass (total mass minus gravel mass) per unit volume. The soil fraction in the size range of 2-75 mm was designated as gravel (Indian Standard Soil Classification System; nptel.ac.in/courses/105103097/ web/chap3final/s6.htm)

\subsection{Statistical analysis}

The statistical analysis of all parameters was done using SAS (2009; SAS Inc., Cary, NC, USA). All parameters were tested using a one-way analysis of variance (ANOVA) and separation of means was subjected to Tukey's honest significant difference test (Steel and Torrie, 1960). Linear regressions using weighted least-square methods were used in Origin v9.0 (OriginLab, Northampton, MA, USA) to identify relationships between the measured parameters. All tests were performed at 0.05 significance level. 

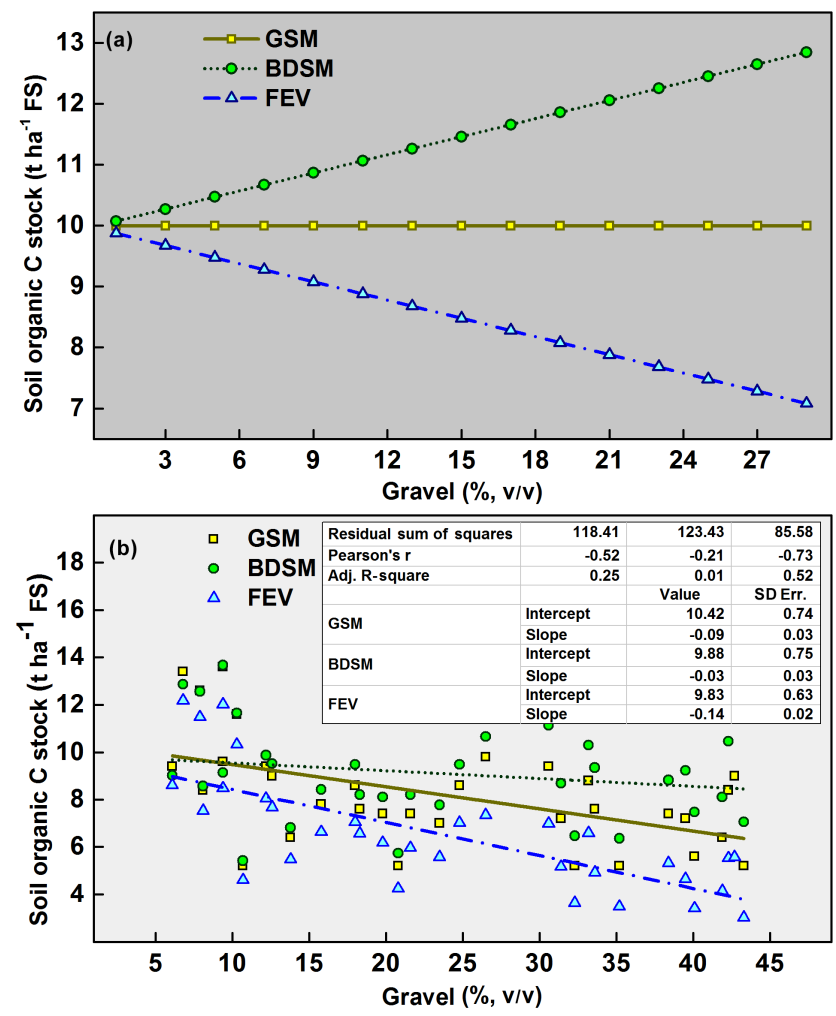

Figure 2. Soil organic C stocks in relation to different proportions of gravel content $(v / v)$ under (a) hypothetical calculations using generalized soil mass of 2.0 million kg furrow soil with $0.5 \%$ soil organic carbon and (b) observations using field soil samples. GSM is the generalized soil mass of $2.0 \times 10^{6} \mathrm{~kg}$ furrow soil, BDSM is the bulk-density-based soil mass and FEV is the fine earth volume. Figure 2a is adapted from Nagaraja and Srinivasamurthy (2009).

\section{Results and discussion}

\subsection{Effect on soil organic C stock}

A hypothetical depiction (Fig. 2a) shows the influence of gravel on soil organic $\mathrm{C}$ in degraded lands when three different soil-mass-volume relationships, namely, generalized soil mass of 2.0 million $\mathrm{kg}$ in 1 ha furrow (GSM; Scenario 1), bulk-density-based soil mass (BDSM, Scenario 2) and the proportion of fine-earth-volume-based soil mass (FEV, Scenario 3) were used. The soil organic $\mathrm{C}$ did not vary with gravel volume when a GSM of 2 million $\mathrm{kg}$ was used in the estimations. However, soil organic $\mathrm{C}$ stock estimations based on BDSM increased with gravel content. Contrastingly, estimations based on the FEV showed a decline in soil organic $\mathrm{C}$. The soil fertility values were also expected to exhibit a similar trend as the hypothetical estimation methodology remains the same. Hypothetically, the soil organic $\mathrm{C}$ stock and nutrient $\left(\mathrm{N}, \mathrm{P}_{2} \mathrm{O}_{5}, \mathrm{~K}_{2} \mathrm{O}\right)$ stock estimates could be of the order Scenario $2($ BDSM $)>$ Scenario $1(\mathrm{GSM})>$ Scenario 3 (FEV).
Analyses based on field-collected samples revealed a decline in soil organic $\mathrm{C}$ with increase in gravel percentage in all the three methods (Fig. 2b). The soil organic C stocks based on BDSM (Scenario 2) were found higher than the GSM method of estimations (Scenario 1). However, the fineearth-proportion-based soil organic C stocks (Scenario 3) remained lower than the other two estimations. The inverse relationships between the soil organic $\mathrm{C}$ stocks and the gravel content in field samples may be attributed to the loss of silt and clay during erosion (Lal, 1995; Rezai and Gilkes, 2005). The accumulation of gravel in the soil layer indirectly reflected the extent of loss of fine soil (Grewal et al., 1984; Lal, 1995). The magnitude of differences among three estimates was found to be the least in soils with low gravel content, and it increased with increase in gravel volume.

In case of hypothetical estimation scenarios (Fig. 2a), the commonly used method of soil organic $\mathrm{C}$ stock estimations, i.e., GSM (Scenario 1), did not bring any change in stocks with different gravel volumes. Contrastingly, with field-sample-based estimations, the stocks declined with increase in gravel content. This was due to the fact that a soil mass of 2 million $\mathrm{kg}$ and soil organic $\mathrm{C}$ of $0.5 \%$ were used in hypothetical estimations, whereas the soil organic $\mathrm{C}$ content declined with gravel volume in field conditions. In case of bulk-density-based estimations (BDSM, Scenario 2), the hypothetical soil organic $C$ stock values increased with gravel content, but in contrast, the values decreased in the fieldsoil-sample-based estimations. The increased soil mass due to the increase in bulk density values with fixed soil organic $\mathrm{C}$ content $(0.5 \%)$ increased the hypothetical soil organic $\mathrm{C}$ stocks, while the decrease in soil organic $\mathrm{C}$ content in the field samples resulted in their reduction. The soil organic $\mathrm{C}$ estimations based on the fine-earth proportion declined in both hypothetical (Fig. 2a) and field-sample-based scenarios (Fig. 2b). This may be attributed to the fact that the fine-earth proportion reduces proportionately with the gravel volume (Nagaraja and Srinivasamurthy, 2009; Grewal et al., 1984). Thus, both the hypothetical and the field-sample-based estimations of soil organic $\mathrm{C}$ stocks remained the same in the order of Scenario $2>$ Scenario $1>$ Scenario 3 .

\subsection{Extent of soil organic C variation}

The magnitude of deviation of soil organic $\mathrm{C}$ values in alternate estimation methods (BDSM and FEV) from GSM were computed for both hypothetical estimations and fieldsample-based values (Fig. 3). The percentage of deviation values revealed a considerable matching of the predicted and the observed values. This indicated that the observed differences between the GSM and the other two methods (BDSM and FEV) in the field estimations correlated well with those of the hypothetical projections.

Comparative analysis of the three methods revealed that the soil organic C stocks derived using BDSM (Scenario 2) were found to be higher than the GSM (Scenario 1). The ac- 
(a)
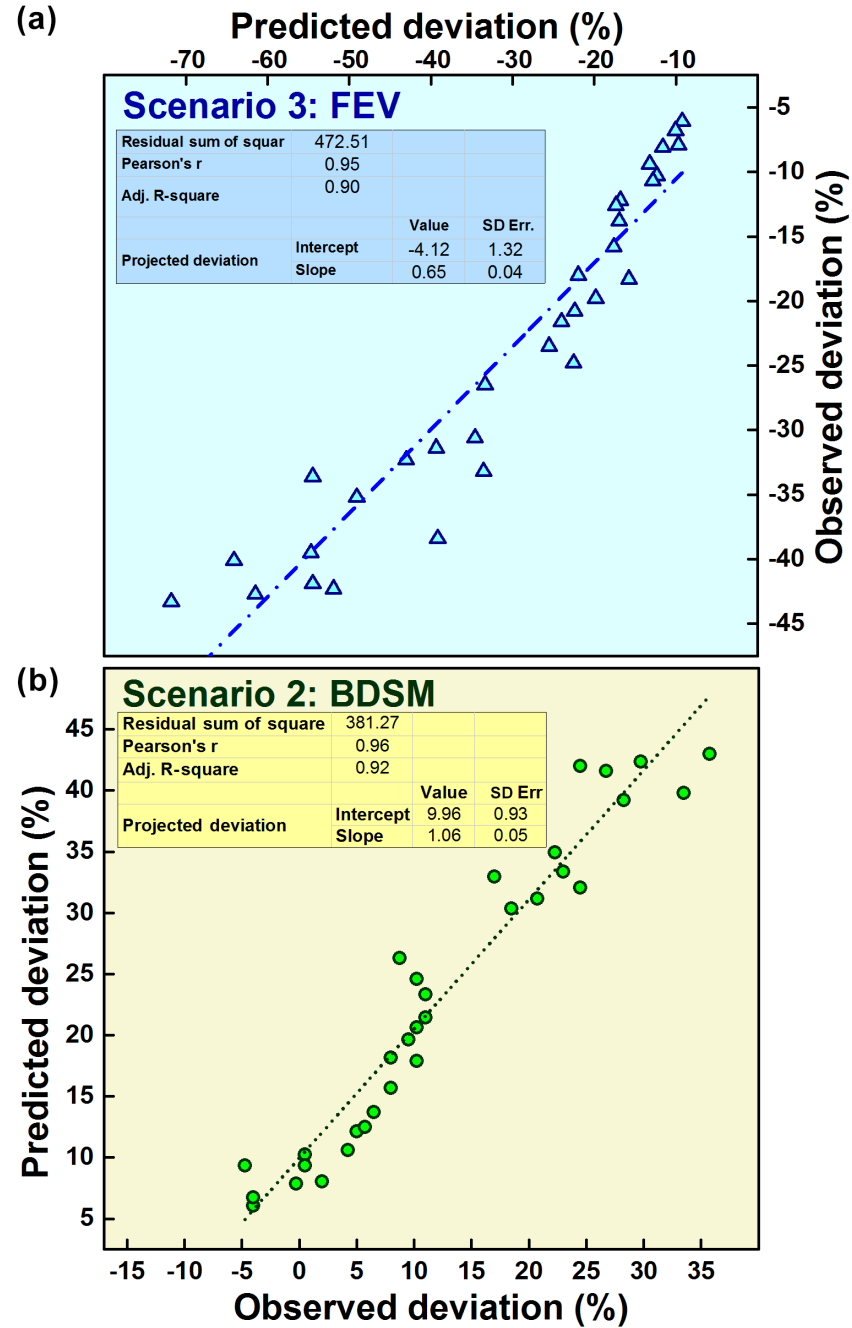

Figure 3. Deviation of the observed soil organic carbon values from the hypothetically estimated values in different methods of soil fertility estimation, where (a) is based on FEV (fine earth volume, Scenario 3) and (b) is based on BDSM (bulk-density-based soil mass, Scenario 2).

cumulation of gravel in the furrow soil volume could add to the soil mass and bulk density values. Contrastingly, the soil organic $\mathrm{C}$ values were lowest in the FEV method compared to the other two methods of estimation. The differences among three estimations were found to be low in soils with lower gravel levels and they increased with an increase in the gravel content. Regression lines developed for three estimations indicated that the differences increased with increase in gravel content. Similar results in arable soils have been reported due to stones and gravel content (Rytter, 2012) and coarse textures (Hamarashid et al., 2010). Changes in bulk density of fine earth (Van Wesemael et al., 2000) and availability of nutrients (Rytter, 2012; Poesen and Lavee, 1994) have also been noted due to rock and coarse fragments. Interestingly, the soil organic $\mathrm{C}$ estimations based on
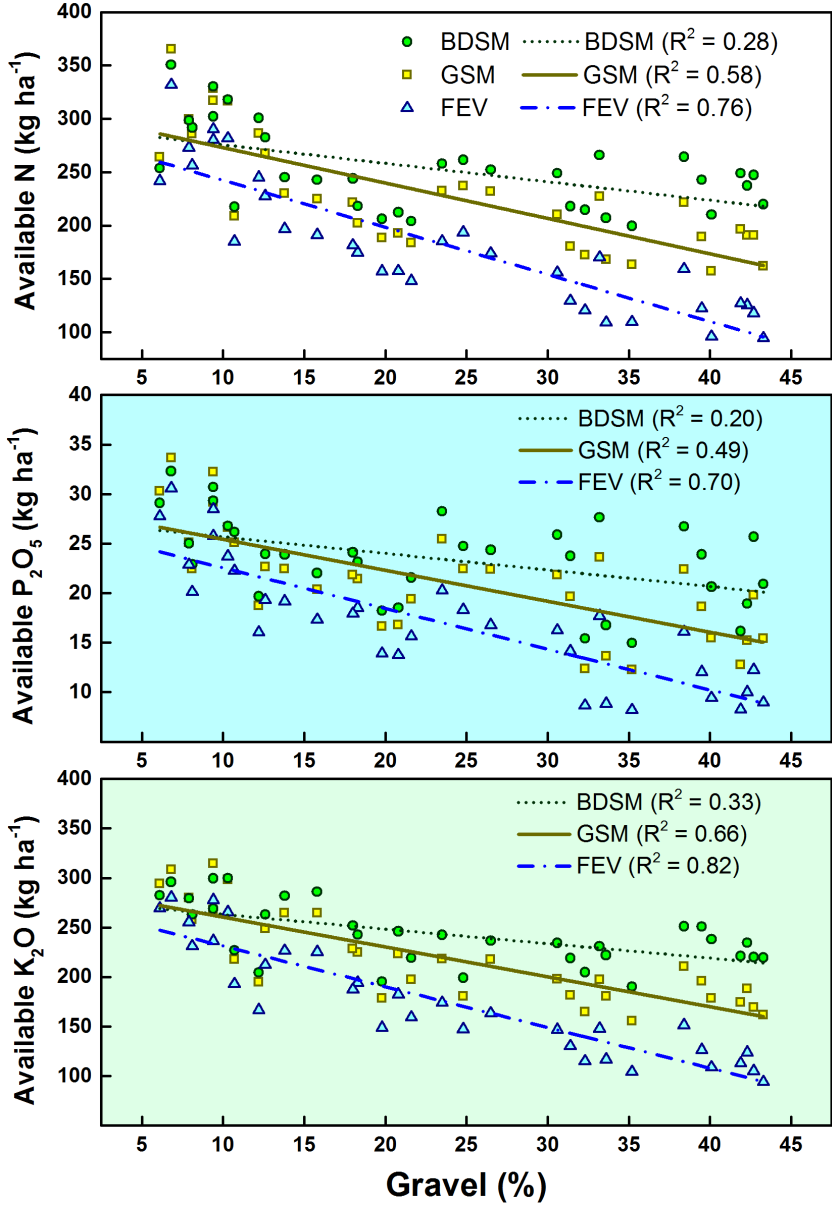

Figure 4. Soil-available $\mathrm{N}, \mathrm{P}_{2} \mathrm{O}_{5}$ and $\mathrm{K}_{2} \mathrm{O}$ in relation to gravel content with GSM (generalized soil mass), BDSM (bulk-density-based soil mass) and FEV (fine-earth-volume-based) estimations.

the FEV recorded higher $R^{2}$ values, while the BDSM estimations recorded the least. These observations suggested that the mass of the soil in the furrow layer is critical in fertility estimations.

\subsection{Effect on available nutrients}

Similar observations were recorded for available nutrients $\left(\mathrm{N}, \mathrm{P}_{2} \mathrm{O}_{5}\right.$ and $\mathrm{K}_{2} \mathrm{O}$ ) (Fig. 4). The available $\mathrm{N}$ (Fig. 4a), $\mathrm{P}_{2} \mathrm{O}_{5}$ (Fig. 4b) and $\mathrm{K}_{2} \mathrm{O}$ (Fig. 4c) revealed the same trends. The explanation for these available nutrient relationships to the method of estimation (GSM, BDSM and FEV) could be traced to soil organic $\mathrm{C}$ trends. The available $\mathrm{N}, \mathrm{P}_{2} \mathrm{O}_{5}$ and $\mathrm{K}_{2} \mathrm{O}$ stocks derived using BDSM were found to be higher than the GSM method. The effects were due to the accumulation of gravel in the furrow soil volume, and the addition to soil mass and bulk density values. The available $\mathrm{N}, \mathrm{P}_{2} \mathrm{O}_{5}$ and $\mathrm{K}_{2} \mathrm{O}$ values were the least in FEV compared to two other methods. The differences, as in soil organic $\mathrm{C}$, were found to increase with an increase in gravel content. Increase in sig- 
nificance $(\mathrm{GSM}<\mathrm{BDSM}<\mathrm{FEV})$ for these comparisons indicated the impacts it might have on nutrient stock estimations based on the method of determination. A variation of $10-120 \%$, depending on gravel content, in all nutrients $(\mathrm{N}$, $\mathrm{P}_{2} \mathrm{O}_{5}, \mathrm{~K}_{2} \mathrm{O}$ ), was noticed due to the method of estimation. Similar variation to an extent of $8 \%$ in $\mathrm{N}$ stock was noted by Rytter (2012) due to stoniness and gravel. We are not familiar with any other study quantifying the effects of gravel on nutrient stocks in agricultural areas at the scale and variation studied in the presented work. As the stones do not allow roots to grow and do not possess nutrient retention abilities, the nutrient estimations based on the GSM or BDSM might only lead to overestimations of nutrients, as noted in this study.

\section{Conclusions}

Our study indicated that the conventional methodology of using generalized soil mass (GSM) or bulk-density-based soil mass (BDSM) in degraded soils would result in overestimation of soil nutrients. These observations indicate that consideration of fine earth volume in the bulk soil could be an important step in nutrient estimation, especially for physically degraded soils with high gravel content. Selective accounting of the fine earth proportion is more applicable to both moderately (15-35\% gravel, $v / v)$ and strongly gravely (35-85\% gravel, $v / v$ ) soils. The generalized soil mass (GSM)-based estimations could be well applicable for soils low in gravel. The extent of variations in the three methods of estimation was low when gravel content was low. However, the magnitude of variations among three estimation methods increases with an increase in gravel content. Thus, selective accounting of fine earth proportion in the bulk volume can be adopted for realistic fertility estimations in degraded soils.

Acknowledgements. The authors thank Y. B. Srinivasa, scientist, Institute of Wood Science and Technology (IWST), Bangalore, and A. Natarajan, National Bureau of Soil Survey and Land Use Planning (NBSS\&LUP), Bangalore, for providing valuable inputs and giving critical comments during the compilation of this paper. Authors also thank the Department of Soil Science, University of Agricultural Sciences, Bangalore, for providing laboratory facility and the Indian Council of Agricultural Research (ICAR), New Delhi, for funding this research project. We are highly thankful to the topical editor of Solid Earth, Artemi Cerdà, for useful suggestions for improving the manuscript further.

Edited by: A. Cerdà

\section{References}

Arvidsson, J.: Nutrient uptake and growth of barley as affected by soil compaction, Plant Soil, 208, 9-19, 1999.
Grewal, S. S., Singh, K., and Dyal, S.: Soil profile gravel concentration and its effect on rainfed crop yields, Plant Soil, 81, 75-83, 1984.

Hamarashid, N. H., Othman, M. A., and Hussain, M. H.: Effects of soil texture on chemical compositions, microbial populations and carbon mineralization in soil, Egypt. J. Exp. Biol., 6, 59-64, 2010.

Hanway, J. J. and Heidel, H.: Soil analysis method as used in Iowa State College Soil Testing Laboratory, Iowa Agriculture, 54, 131, 1952.

Hartemink, A. E.: Assessing soil fertility decline in the tropics using soil chemical data, Adv. Agron., 89, 179-225, 2006.

Heisner, U., Raber, B., and Hildebrand, E. E.: the importance of the soil skeleton for plant available nutrients in sites of the Southern Black Forest, Germany, Eur. J. For. Res., 123, 249-257, 2004.

Jagadamma, S., Lal, R., and Rimal, B. K.: Effects of topsoil depth and soil amendments on corn yield and properties of two Alfisols in Central Ohio, J. Soil Water Conserv., 64, 70-80, 2009.

Jalota, S. K., Khera, R., and Bhuman, B. S.: Methods in Soil Physics. Narosa Publishing House, Ludhiana, India, 1998.

Kaleeem Abbasi, M., Mahmood Tahir, M., Sabir, N., and Khurshid, M.: Impact of the addition of different plant residues on nitrogen mineralization-immobilization turnover and carbon content of a soil incubated under laboratory conditions, Solid Earth, 6, 197205, doi:10.5194/se-6-197-2015, 2015.

Karlen, D. L., Ditzler, C. A., and Andrews, S. S.: Soil quality: why and how?, Geoderma, 114, 145-156, 2003.

Kohler, M., Von Wilpert, K., and Hildebrand, E. E.: The soil skeleton as a source for the short term supply of "basic cations" in forest soils of the Black Forest, Water Air Soil Poll., 122, 37-48, 2000.

Lal, R.: Erosion-crop productivity relationships for soils of Africa, Soil Sci. Soc. Am. J., 59, 661-667, 1995.

Lorenz, K. and Lal, R.: The Depth Distribution of Soil Organic Carbon in Relation to Land Use and Management and the Potential of Carbon Sequestration in Subsoil Horizons, Adv. Agron., 88, 35-66, 2005.

Lozano-Garcia, B. and Parras-Alcantara, L.: Variation in soil organic carbon and nitrogen stocks along a topo sequence in a traditional Mediterranean olive grove, Land Degrad. Dev., 25, 297304, 2014.

Lozano-Garcia, B., Parras-Alcantara, L., and Brevik, E.C.: Impact of topographic aspect and vegetation (native and reforested areas) on soil organic carbon and nitrogen budgets in Mediterranean natural areas, Sci. Total Environ., 544, 963-970, 2016.

Mebius, L. J.: A rapid method for the determination of organic carbon in soil, Anal. Chim. Acta, 22, 120-124, 1960.

Mishra, V. K., Srivastava, S., Bhardwaj, A. K., Sharma, D. K., Singh, Y. P., and Nayak, A. K.: Resource conservation strategies for rice-wheat systems on partially reclaimed sodic soils of the Indo-Gangetic region, and their effects on soil carbon, Nat. Resour. Forum, 39, 110-122, 2015.

Nagaraja, M. S. and Srinivasamurthy, C. A.: Soil fertility in physically degraded soils: Are we over estimating?, Curr. Sci. India, 97, 1534-1536, 2009.

Olsen, S. R., Cole, C. V., Watanabe, F. S., and Dean, L. A.: Estimation of available phosphorus in soils by extraction with sodium bicarbonate, United States Department of Agriculture Circular, 939, 1-19, 1954. 
Parras-Alcantara, L., Lozano-Garcia, B., Brevik, E. C., and Cerda, A.: Soil organic carbon stocks assessment in Mediterranean natural areas: A comparison of entire soil profiles and soil control sections, J. Environ. Manage., 155, 219-228, 2015.

Pierce, F. J., Larson, W. E., Dowdy, R. H., and Graham, W. A. P.: Productivity of soils: Assessing long-term changes due to erosion, J. Soil Water Conserv., 38, 39-44, 1983.

Pimentel, D., Harvey, C., Resosudarmo, P., Sinclair, K., Kurz, D., McNair, M., Crist, S., Shpritz, L., Fitton, L., Saffouri, R., and Blair, R.: Environmental and economic costs of soil erosion and conservation benefits, Science, 267, 1117-1123, 1995.

Poesen, J. and Lavee, H.: Rock fragments in top soils, significance and processes, Catena, 23, 1-28, 1994.

Ramachandra, T. V., Kamakshi, G., and Shruthi, B. V.: Bioresource status in Karnataka, Renew. Sust. Energ. Rev., 8, 1-47, 2004.

Rao, D. V. K. N. and Jessy, M. D.: Impact of effective soil volume on growth and yield of rubber (Hevea brasiliensis), Geoderma, 141, 332-340, 2007.

Rezaei, S. A. and Gilkes, R. J.: The effects of landscape attributes and plant community on soil chemical properties in rangelands, Geoderma, 125, 167-176, 2005.

Rytter, R. M.: Stone and gravel contents of arable soils influence estimates of C and N stocks, Catena, 95, 153-159, 2012.

SAS Institute: The JMP system for Windows, Release 9.1, SAS Inst., Cary, NC, USA, 2009.

Schumacher, B. A.: Methods for the determination of total organic carbon (toc) in soils and sediments, available at: http: //www.epa.gov/esd/cmb/research/papers/bs116.pdf (last access: 9 March 14), 2002.
Silver, W. L., Neff, J., McGroddy, M., Veldkamp, E., Keller, M., and Cosme, R.: Effects of soil texture on belowground carbon and nutrient storage in a lowland Amazonian forest ecosystem, Ecosystems, 3, 193-209, 2000.

Soil Survey Division Staff: Soil survey manual, Soil Conservation Service, US Department of Agriculture Handbook, 18, 46-155, 1993.

Soils of Karnataka: Soils of Karnataka for optimizing Land use, NBSS\&LUP Publication no. 47, Nagpur, India, 1998.

Srinivasarao, C., Venkateswarlu, B., Lal, R., Singh, A. K., Kundu, S., Vittal, K. P. R., Patel, J. J., and Patel, M. M.: Long-term manuring and fertilizer effects on depletion of soil organic carbon stocks under pearl millet-cluster bean-castor rotation in Western India, Land Degrad. Dev., 25, 173-183, 2014.

Steel, R. G. D. and Torrie, J. H.: Principle and procedures of statistics, McGraw, New York, 106-107, 1960.

Subbiah, B. V. and Asija, G. L.: A rapid procedure for determination of available nitrogen in soils, Curr. Sci. India, 25, 259-260, 1956.

Van Wesemael, B., Mulligan, M., and Poesen, J.: Spatial patterns of soil water balance on intensively cultivated hill slopes in a semiarid environment, the impact of rock fragments and soil thickness, Hydrol. Proc., 14, 1811-1828, 2000.

Zubrzycki, S., Kutzbach, L., and Pfeiffer, E.-M.: Permafrostaffected soils and their carbon pools with a focus on the Russian Arctic, Solid Earth, 5, 595-609, doi:10.5194/se-5-595-2014, 2014. 